\title{
Risk Assessment of the Large-Scale Hydrogen Storage in Salt Caverns
}

\author{
Maria Portarapillo *[D and Almerinda Di Benedetto
}

check for

updates

Citation: Portarapillo, M.; Di Benedetto, A. Risk Assessment of the Large-Scale Hydrogen Storage in Salt Caverns. Energies 2021, 14, 2856. https://doi.org/10.3390/en14102856

Academic Editor: Ben McLellan

Received: 12 April 2021

Accepted: 10 May 2021

Published: 15 May 2021

Publisher's Note: MDPI stays neutral with regard to jurisdictional claims in published maps and institutional affiliations.

Copyright: (c) 2021 by the authors. Licensee MDPI, Basel, Switzerland. This article is an open access article distributed under the terms and conditions of the Creative Commons Attribution (CC BY) license (https:// creativecommons.org/licenses/by/ $4.0 /)$.
Department of Chemical, Materials and Production Engineering, University of Naples Federico II, 80125 Naples, Italy; almerinda.dibenedetto@unina.it

* Correspondence: maria.portarapillo@unina.it

\begin{abstract}
Salt caverns are accepted as an ideal solution for high-pressure hydrogen storage. As well as considering the numerous benefits of the realization of underground hydrogen storage (UHS), such as high energy densities, low leakage rates and big storage volumes, risk analysis of UHS is a required step for assessing the suitability of this technology. In this work, a preliminary quantitative risk assessment (QRA) was performed by starting from the worst-case scenario: rupture at the ground of the riser pipe from the salt cavern to the ground. The influence of hydrogen contamination by bacterial metabolism was studied, considering the composition of the gas contained in the salt caverns as time variable. A bow-tie analysis was used to highlight all the possible causes (basic events) as well as the outcomes (jet fire, unconfined vapor cloud explosion (UVCE), toxic chemical release), and then, consequence and risk analyses were performed. The results showed that a UVCE is the most frequent outcome, but its effect zone decreases with time due to the hydrogen contamination and the higher contents of methane and hydrogen sulfide.
\end{abstract}

Keywords: underground hydrogen storage; risk analysis; hydrogen contamination

\section{Introduction}

Large-scale hydrogen storage plays a crucial role in the potential future clean hydrogen economy. Indeed, both the production of hydrogen from processes with a low or zero carbon footprint [1-5] and the research of cost-effective and high-capacity storage methods are at the core of developing the hydrogen economy. This could aid climate goals because hydrogen only emits water when burned and can be made without releasing $\mathrm{CO}_{2}$. However, its production currently emits 830 million tons of $\mathrm{CO}_{2}$ each year [6].

Once produced, hydrogen has to be transported, distributed and stored. The storage of hydrogen is very challenging due to its very low density $(0.08988 \mathrm{~g} / \mathrm{L}$ at standard temperature and pressure) [7]. Thus, to reduce both the capital (CAPEX) and operational expenditure (OPEX), the hydrogen storage density must be increased. All of the methods to store hydrogen at an increased density require some input of energy in the form of work (e.g., for its compression), heat or, in some cases, hydrogen-binding materials [7]. As regards gas storage, depending on the volume to be stored and the local conditions, it can either be on the surface, such as tube storage, or underground, preferably in salt caverns [8]. Salt caverns at depths of several hundreds of meters offer many benefits for the realization of underground hydrogen storage (UHS), including high energy densities, low construction costs and specific investment costs per megawatt-hour of storage, low leakage rates (considering the amount of stored hydrogen), big storage volumes (about 500,000 $\mathrm{m}^{3}$ for several thousand tons of hydrogen) and minimal risks of hydrogen contamination [9]. Indeed, the high operational pressure of the caverns (60-180 bar) allows high energy densities. More precisely, for a low-pressure vessel, it is $30 \mathrm{kWhel} / \mathrm{m}^{3}$ at $20 \mathrm{bar}$; for pipe storage, it is $120 \mathrm{kWhel} / \mathrm{m}^{3}$ at $80 \mathrm{bar}$; and for salt caverns, it can be as high as $300 \mathrm{kWhel} / \mathrm{m}^{3}$ at 200 bar [8]. 
Four types of underground hydrogen storage can be distinguished depending on the $\mathrm{H}_{2}$ purity and its final destination:

- Underground pure hydrogen storage: the destination of this hydrogen is for use in fuel cells;

- Underground storage of natural gas and hydrogen (6-15\%): the mixture is used as fuel;

- Underground storage of rich hydrogen mixture with $\mathrm{CO}, \mathrm{CH}_{4}$ and $\mathrm{CO}_{2}$ (syngas or town gas): the mixture is used as electricity (through thermo-mechanical conversion in gas turbines) and/or as fuel;

- Underground methanation reactor (UMR): the objective of such storage is to enrich the energy potential of the gas by transforming the mixture of $\mathrm{H}_{2}$ and $\mathrm{CO}_{2}$ into methane through the action of methanogenic bacteria [10].

Unfortunately, the distribution of salt deposits overall is not equal (mainly located in the UK and USA). However, for many years, a small number of salt caverns have also been used to store hydrogen. For instance, hydrogen storage facilities of this kind are in Teesside, Great Britain (three caverns, 70,000 $\mathrm{m}^{3}$ each, depth $370 \mathrm{~m}$ ); Clemens Dome, Texas (one cavern, 580,000 $\mathrm{m}^{3}$, depth 1000-1300 m); and Moss Bluff, Texas (one cavern, 566,000 m³, depth 335-1400 m).

Several papers and reports have focused on the scientific aspects of hydrogen storage in geological structures, and they all conclude that hydrogen storage poses issues comparable to those of the storage of natural gas [11-14], with the exception of the negligible losses of hydrogen by diffusion through salt walls in caverns [15]. Starting from the first in situ analysis of the gases in underground gas storage in Lobodice, the unusual behavior of hydrogen was shown [16]. The mechanisms of gas pollution in salt caverns are mainly caused by the presence of bacteria. They live in the sump at the bottom (up to $30 \%$ of the total cavern volume) and, in the presence of sulfates and carbonates, consume hydrogen, producing $\mathrm{H}_{2} \mathrm{~S}$ and/or methane [10]. In particular, in situ generation of methane from hydrogen and $\mathrm{CO}_{2}$ or $\mathrm{CO}$, according to the Sabatier reaction, can occur at high temperatures $\left(800{ }^{\circ} \mathrm{C}\right)$ in the presence of a catalyst (nickel) or at low temperatures $\left(30-40^{\circ} \mathrm{C}\right.$ ) in the presence of microorganisms (Methanogenic Archaea) [10]. Moreover, acetogenic bacteria convert hydrogen and $\mathrm{CO}_{2}$ into acetate. The $\mathrm{CO}_{2}$ needed for these reactions in UHS is frequently present in the injected gas (in the case of town gas), found in carbonaceous reservoir rocks and/or generated through the decomposition of acetate produced by hydrogenotrophic bacteria. The optimal pressure and temperature for the growth of methanogenic and acetogenic bacteria are 90 bar and $30-40{ }^{\circ} \mathrm{C}$, respectively, but they are capable of growing even at $97^{\circ} \mathrm{C}[10]$ and 750 bar $[17,18]$. Moreover, the abiotic redox reactions induced by hydrogen are significant at temperatures below $100{ }^{\circ} \mathrm{C}$ without special catalysts. For instance, the reaction rate of the reduction of pyrite rocks $\left(\mathrm{FeS}_{2}\right)$ into pyrrhotite $\left(\mathrm{FeS}_{1+\mathrm{x}}\right)$ and hydrogen sulfide remains significant even at $50{ }^{\circ} \mathrm{C}$ [19]. $\mathrm{H}_{2} \mathrm{~S}$ is also produced by sulfate (from rocks) reduction promoted by archaeoglobus bacteria. The reduction is favorited by high temperatures (higher than $92{ }^{\circ} \mathrm{C}$ ) [10]. Due to the critical influence of bacterial metabolism on hydrogen stored purity, the general recommendation is to analyze the relevant microbiological characteristics of each underground site (salt caverns, deep aquifers, oil and gas reservoirs) to establish a good monitoring system of potential microbial side effects [20].

Every different hydrogen storage method shows peculiar safety problems. Generally, hydrogen has a low ignition temperature and a wide flammability range, making leaks a significant hazard for fire and explosion, especially in confined spaces. Moreover, in the case of UHS in salt caverns, due to the phenomenon of hydrogen contamination by bacterial metabolism, the hazards associated with the presence of methane and hydrogen sulfide must also be considered. Consequently, risk analysis of $\mathrm{H}_{2}$ underground storage is a required step for assessing the suitability of this technology.

To the best of our knowledge, although quantitative risk assessment of underground hydrocarbon storage has been widely performed [21,22], no previous work has been 
published on the risk analysis of salt caverns used for hydrogen storage. Indeed, in recent studies [23-26], all of the potential, limits and risks of underground storage have been highlighted. Particularly, the key issues addressed in these papers are the change in capacity and efficiency of UGS associated with the blending of hydrogen in the stored natural gas, the geological integrity of the reservoir and cap rocks, the technical integrity of gas storage wells, the durability of the materials used for well completion, corrosion, leakage and environmental risks associated with the products of microbial metabolism [23-26]. None of these works contain a risk assessment for the case of leakage or any other accidental scenario. In this work, a risk analysis of UHS was carried out by starting from the worstcase scenario: rupture at the ground of the riser pipe from the salt cavern to the ground. The risk analysis was performed by assuming the release of hydrogen, methane and hydrogen sulfide with different compositions and as a function of time. In this way, this work can be considered a preliminary tool for understanding the risk associated with large-scale storage of hydrogen through the exploitation of natural salt caverns.

\section{Materials and Methods}

The properties of the involved chemical species are summarized in Table 1. As can be seen, the properties of sulfur dioxide are listed, as $\mathrm{SO}_{2}$ can be produced through $\mathrm{H}_{2} \mathrm{~S}$ complete combustion (e.g., in the case of jet fire), causing a toxic chemical release.

Table 1. Properties of the involved agents by NIST database [27].

\begin{tabular}{ccccc}
\hline Properties & $\mathbf{H}_{\mathbf{2}}$ & $\mathbf{C H}_{\mathbf{4}}$ & $\mathbf{H}_{\mathbf{2}} \mathbf{S}$ & $\mathbf{S O}_{\mathbf{2}}$ \\
\hline Heat of combustion $\Delta \mathrm{H}_{\mathrm{c}}(\mathrm{kJ} / \mathrm{kg})$ & 141,584 & 55,514 & 15,264 & - \\
LFL (ppm) & 40,000 & 50,000 & 40,000 & - \\
UFL (ppm) & 750,000 & 150,000 & 440,000 & - \\
TLV-STEL (ppm) & - & - & 5 & 5 \\
TLV-TWA (ppm) & - & - & 1 & 2 \\
AEGL-1 (60 min) $(\mathrm{ppm})$ & - & - & 0.51 & 0.2 \\
\hline
\end{tabular}

The composition of the gas contained in the salt caverns was considered as time variable. In particular, the data obtained by Hemme and van Berk [28] at 2.5, 21 and 30 years were considered. They developed a model of the hydrogeochemical mechanisms of underground hydrogen stored at $160 \mathrm{~atm}$ and $80^{\circ} \mathrm{C}$, involving the reactions of bacterial metabolism, the interactions with reservoir and cap rocks and the loss of aqueous $\mathrm{H}_{2}(\mathrm{aq})$ by diffusion through the cap rocks. It is worth underlining that there are several studies on the effect of bacterial activity on the composition of underground stored gas $[16,25,29-31]$. Unfortunately, no other studies have detailed the composition of stored gas as reported in Hemme and van Berk work [28], nor are there any data that vary over time.

Figure 1 shows the hydrogen, methane and hydrogen sulfide molar fractions as a function of time [28]. The molar compositions at 2.5, 21 and 30 years are given in Table 2. These times were chosen in order to have three different scenarios. At the earlier time, a higher hydrogen content is present in the stored gas. At 21 years, the hydrogen content is equal to that of methane, while at 30 years, the maximum contents of methane and, above all, hydrogen sulfide are present. $\mathrm{H}_{2} \mathrm{~S}$ introduces toxic chemical release problems, both as it is and also when oxidized to $\mathrm{SO}_{2}$. 


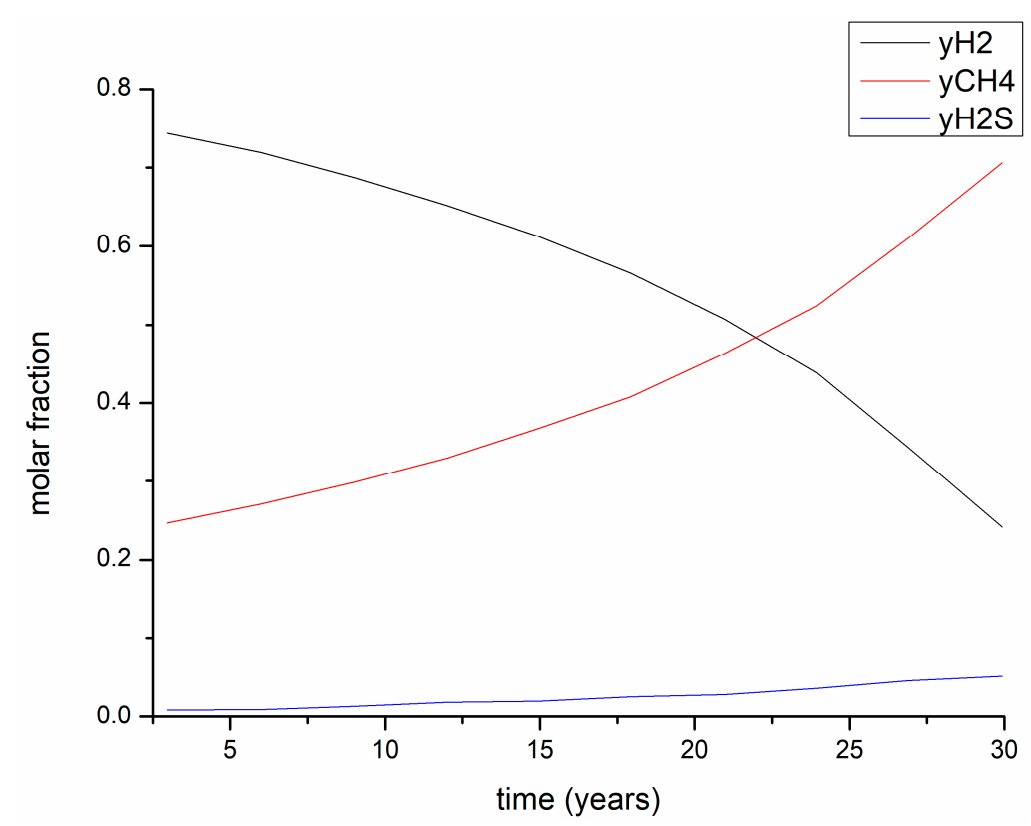

Figure 1. Hydrogen (black), methane (red) and hydrogen sulfide (blue) molar fractions as a function of time (years) [28].

Table 2. Composition of the gas stored in the salt cavern at 2.5, 21 and 30 years as computed by Hemme and van Berk [28].

\begin{tabular}{cccc}
\hline Components & 2.5 Years & 21 Years & 30 Years \\
\hline $\mathrm{H}_{2}$ & $74.37 \%$ & $50.72 \%$ & $24.18 \%$ \\
$\mathrm{CH}_{4}$ & $24.69 \%$ & $46.37 \%$ & $70.59 \%$ \\
$\mathrm{H}_{2} \mathrm{~S}$ & $0.94 \%$ & $2.8 \%$ & $5.23 \%$ \\
\hline
\end{tabular}

In the calculations, a riser pipe from the salt cavern to the ground, $820 \mathrm{~m}$ long (e.g., in the case of the salt cavern of Bad Lauchstadt, $500,000 \mathrm{~m}^{3}$ ), with an internal diameter equal to $250 \mathrm{~mm}$, was considered. Such a diameter is used to reduce the mass flow rate in case of incidents [22]. Modern plant designs include a subsurface valve, which should prevent complete loss of pressure in a cavern from any event at the surface. The duration of any jet flame and gas release depends on the time taken for automatic closure of the valves in the system [22]. If the valve operates correctly, any jet flame or gas release should last only a few minutes [22]. Consequently, in this work, a duration of 1 min was used.

To calculate the mass flow rate, adiabatic expansion of the gas, which is the worst scenario (highest mass flow rate), was assumed [32]. In this condition, for long pipes and large pressure differences across the pipe, the velocity of the gas approaches the sonic velocity (choked flow). The consequence of a serious failure at the wellhead is a high-velocity gas jet.

The possible outcomes (and their frequencies [33]) as well as the main possible causes (basic events) [33] are reported in the bow-tie diagram shown in Figure 2. The incident frequency as well as the immediate/delayed ignition probabilities were reported in the literature $[33,34]$. According to the event tree analysis, by implementing logical and arithmetic computation methods, the possible outcomes are jet fire with toxic $\mathrm{SO}_{2}$ release, unconfined vapor cloud explosion (UVCE) with the highest frequency and toxic $\mathrm{H}_{2} \mathrm{~S}$ release. 


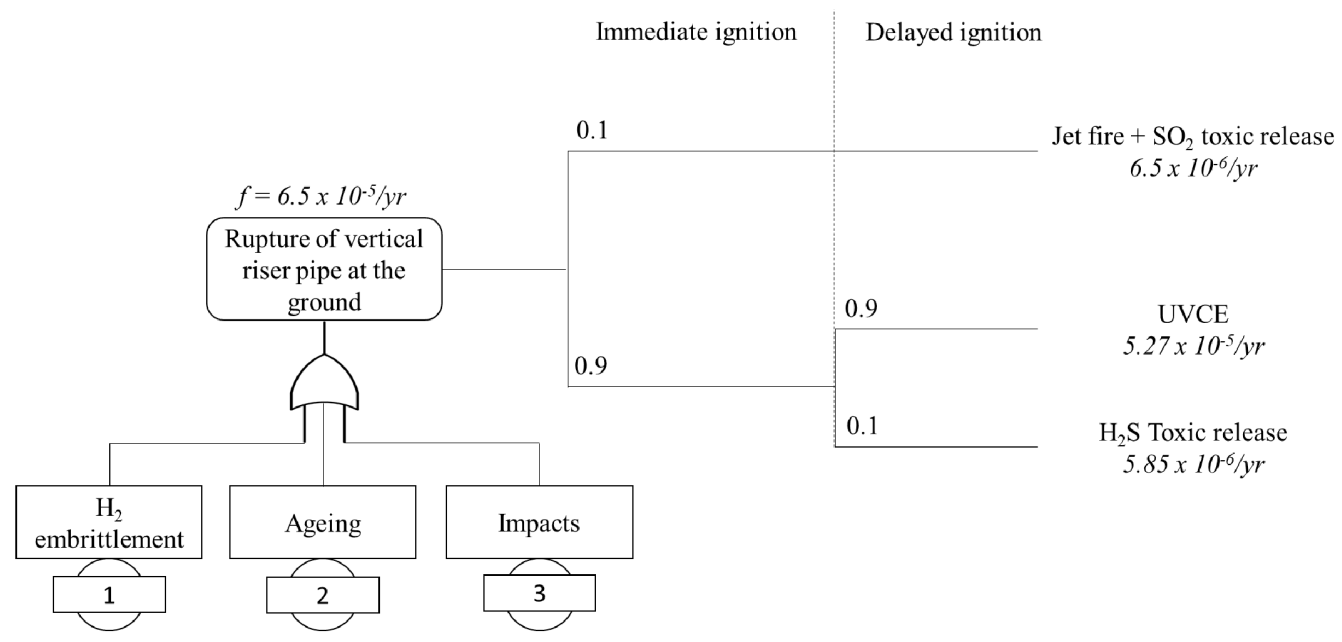

Figure 2. Bow-tie diagram with "Rupture of vertical riser pipe at the ground" as initiating event/top event.

The gas jet can be immediately ignited producing a jet flame. To calculate the height of the flame, the method by Mudan and Croce (1988) (Equation (1)) was used [35].

$$
\frac{L}{d_{j}}=\frac{5.3}{C_{T}}\left\{\frac{T_{f} / T_{j}}{\alpha_{T}}\left(C_{T}+\frac{\left(1-C_{T}\right) M_{a}}{M_{f}}\right)\right\}
$$

where:

$L$ is the length of the visible turbulent flame measured from the break point (m);

$D_{j}$ is the diameter of the jet-that is, the physical diameter of the nozzle $(\mathrm{m})$;

$\mathrm{C}_{T}$ is the fuel mole fraction concentration in a stoichiometric $\mathrm{H}_{2} / \mathrm{CH}_{4} / \mathrm{H}_{2} \mathrm{~S}$-air mixture (-); $T_{f}$ and $T_{j}$ are the adiabatic flame temperature and jet fluid temperature, respectively $(\mathrm{K})$; $\alpha_{T}$ is the moles of reactant per mole of product for a stoichiometric fuel-air mixture (-); $M_{a}$ is the molecular weight of the air $(\mathrm{g} / \mathrm{mol})$;

$M_{f}$ is the molecular weight of the fuel $(\mathrm{g} / \mathrm{mol})$.

The radiative flux received by a source was calculated by using a procedure similar to the point source method. The radiant flux at the receiver at a distance $\mathrm{x}$ is determined from Equation (2) [36]:

$$
E_{r}=\tau_{a} \eta G \Delta H_{c} F_{p}
$$

where:

$E_{r}$ is the radiant flux at the receiver $\left(\mathrm{kW} / \mathrm{m}^{2}\right)$;

$\tau_{a}$ is the atmospheric transmissivity (-);

$F_{p}$ is the point source view factor $\left(\mathrm{m}^{2}\right)$;

$\eta$ is the fraction of total energy converted to radiation (-);

$G$ is the mass flow rate of the fuel $(\mathrm{kg} / \mathrm{s})$;

$\Delta H_{c}$ is the heat of combustion of the fuel $(\mathrm{kJ} / \mathrm{kg})$.

In addition to the effects related to thermal radiation, the combustion of $\mathrm{H}_{2} \mathrm{~S}$ forms sulfur dioxide $\left(\mathrm{SO}_{2}\right)$, which is mildly toxic and can be hazardous at high concentrations. Long-term exposure to low concentrations is also problematic [37]. For this reason, the dispersion of $\mathrm{SO}_{2}$ was also taken into account.

In the case of non-immediate ignition, the vapor cloud disperses into the environment. Then, it can be ignited, resulting in an unconfined vapor cloud explosion (flammable species: $\mathrm{H}_{2}, \mathrm{CH}_{4}$ and $\mathrm{H}_{2} \mathrm{~S}$ ). In the case of no ignition, the outcome is a toxic chemical release due to the presence of $\mathrm{H}_{2} \mathrm{~S}$. Thus, considering neutrally buoyant models as a good approximation of the behavior of any vapor cloud at some distance downwind from its release, a Gaussian dispersion model (in particular, the Pasquill-Gifford plume model) was used [36]. Moreover, through the use of the dimensionless downwind distance and area, 
the total isopleth area $\mathrm{A}\left(\mathrm{m}^{2}\right)$ at the target concentration (i.e., the low flammable limit of the mixture) was calculated [36]. The obtained trend of the average concentration was used for the UVCE calculation effect.

The explosion effects were modeled through the TNT equivalency model [36], where the flammable amount in the cloud $\mathrm{M}_{\mathrm{e}}(\mathrm{kg})$ is quantified through van Buijtenen's model for continuous release [38]. Several techniques are available for predicting the strength of the blast wave produced by an unconfined vapor cloud explosion as a function of the distance from the vapor cloud. In recent works, the TNT model, TNO model, Baker-Strehlow-Tang (BST) model and Dorofeev model have been used to predict the strength of hydrogen unconfined cloud explosions. The results indicate that the TNT model predicts higher explosion overpressures at the same distance compared to the others [39-42].

Regarding van Buijtenen's model, it was derived through a three-dimensional integration of the Gaussian plume model equation [38]. Given the derivation of the formula for the calculation of the flammable mass in a cloud, this can be used for any species for which the Gaussian dispersion model is suitable, or, as in our case, at long distance from the source, where the passive dispersion prevails over the buoyancy. Moreover, there are applications of this model in the case of hydrogen in risk analysis manuals $[43,44]$.

For the toxic release of $\mathrm{H}_{2} \mathrm{~S}$ and $\mathrm{SO}_{2}$ (obtained from complete combustion of $\mathrm{H}_{2} \mathrm{~S}$ ), the Britter-McQuaid model for dense gas dispersion was used [45]. Detailed comparisons of dense gas dispersion model predictions with field test data have been performed over the years, and the Britter-McQuaid model produces remarkably good results with predictions outperforming many more complex models for many chemicals (also for $\mathrm{H}_{2} \mathrm{~S}$ and $\mathrm{SO}_{2}$ ) [46,47]. Given the simplicity of the model, the Britter-McQuaid model is widely used for the preliminary assessment of the risk of dispersal of these agents in several technical reports $[48,49]$.

Table 3 summarizes the data used for all calculations.

Table 3. Summary of data used for the calculations.

\begin{tabular}{cccc}
\hline & Value & & Value \\
\hline Pipe length $(\mathrm{m})$ & 820 & Ambient pressure (atm) & 1 \\
Pipe diameter $(\mathrm{m})$ & 0.25 & Relative humidity $(\%)$ & 50 \\
Pipe roughness $(\mathrm{m})$ & 0.000015 & Explosion efficiency $(-)$ & 0.02 \\
Storage pressure $(\mathrm{atm})$ & 160 & Discharge coefficient $\mathrm{C}_{0}$ & 1 \\
Storage temperature $\left({ }^{\circ} \mathrm{C}\right)$ & 80 & Wind speed $(\mathrm{m} / \mathrm{s})$ & 2 \\
Leak height $(\mathrm{m})$ & 0 & Ground roughness & Open country \\
Leak diameter $(\mathrm{m})$ & 0.25 & Cloud cover & $10 / 10$ \\
Ambient temperature $\left({ }^{\circ} \mathrm{C}\right)$ & 25 & Stability class & $\mathrm{F}$ \\
\hline
\end{tabular}

\section{Results}

\subsection{Source Model Results}

The results of the mass flow rate calculations are given in Table 4. It is shown that the release conditions (i.e., temperature and pressure) are comparable in all of the investigated cases. However, the mass flow rate increases with time as the hydrogen content (lighter component) decreases, while the contents of the heavier components $\left(\mathrm{CH}_{4}\right.$ and $\mathrm{H}_{2} \mathrm{~S}$ ) increase.

Table 4. Mass flow rate calculation results at 2.5, 21 and 30 years.

\begin{tabular}{cccc}
\hline & 2.5 Years & 21 Years & 30 Years \\
\hline $\operatorname{Ma}_{1}(-)^{1}$ & 0.13 & 0.14 & 0.14 \\
$\mathrm{G}_{\text {choked }}(\mathrm{kg} / \mathrm{s})^{2}$ & 174.38 & 223.01 & 267.41 \\
$\mathrm{P}_{\text {choked }}(\mathrm{bar})^{3}$ & 19.81 & 20.03 & 20.28 \\
$\mathrm{~T}_{\text {choked }}\left({ }^{\circ} \mathrm{C}\right)^{4}$ & 340.40 & 340.95 & 341.60
\end{tabular}

${ }^{1}$ Upstream Mach number. ${ }^{2}$ Downstream mass flow rate for adiabatic choked flow. ${ }^{3}$ Downstream choked pressure. ${ }^{4}$ Downstream choked temperature. 


\subsection{Jet Fire Results}

The results of the jet fire calculations are given in Table 5. In the case of a jet fire, there are a few differences between the three examined cases. In the long term (30 years), the size of the jet fire increases, resulting in a greater exposed radiative surface and in greater level of concern (LOC) iso-level areas than in the other two cases.

Table 5. Jet fire calculation results, thermal radiation level of concern (LOC) [50] and relative distance downwind at 2.5, 21 and 30 years.

\begin{tabular}{cccc}
\hline & 2.5 Years & 21 Years & 30 Years \\
\hline$\Delta \mathrm{H}_{\mathrm{c}}(\mathrm{kJ} / \mathrm{kg})^{1}$ & $75,526.93$ & $60,572.31$ & $53,306.28$ \\
$\mathrm{~T}_{\mathrm{f}}(\mathrm{K})$ & 2767.33 & 2668.06 & 2605 \\
$\mathrm{~T}_{\mathrm{j}}(\mathrm{K})$ & 340.40 & 340.95 & 341.60 \\
$\eta(-)$ & 0.2 & 0.2 & 0.2 \\
$\mathrm{M}_{\mathrm{a}}(\mathrm{g} / \mathrm{mol})$ & 29 & 29 & 29 \\
$\mathrm{M}_{\mathrm{f}}(\mathrm{g} / \mathrm{mol})$ & 5.76 & 9.42 & 13.56 \\
$\mathrm{C}_{\mathrm{T}}(-)$ & 0.19 & 0.15 & 0.12 \\
$\alpha_{\mathrm{T}}(-)$ & 1.08 & 1.04 & 1.01 \\
$\mathrm{~L}(\mathrm{~m})$ & 39 & 41 & 44 \\
$\mathrm{P}_{\mathrm{w}}(\mathrm{Pa})^{2}$ & 14,643 & 15,023 & 15,467 \\
\hline$\downarrow$ LOC $\backslash$ Distance $\rightarrow$ & $\mathbf{2 . 5}$ Years & $\mathbf{2 1}$ Years & $\mathbf{3 0}$ Years \\
\hline $37.5 \mathrm{~kW} / \mathrm{m}^{2}$ & $54 \mathrm{~m}$ & $55 \mathrm{~m}$ & $56 \mathrm{~m}$ \\
$12.5 \mathrm{~kW} / \mathrm{m}^{2}$ & $95 \mathrm{~m}$ & $97 \mathrm{~m}$ & $99 \mathrm{~m}$ \\
$5 \mathrm{~kW} / \mathrm{m}^{2}$ & $150 \mathrm{~m}$ & $150 \mathrm{~m}$ & $155 \mathrm{~m}$ \\
$2 \mathrm{~kW} / \mathrm{m}^{2}$ & $230 \mathrm{~m}$ & $235 \mathrm{~m}$ & $240 \mathrm{~m}$ \\
\hline
\end{tabular}

${ }^{1}$ Mass fraction averaged heat of combustion. ${ }^{2}$ Water vapor partial pressure for the transmissivity calculation.

\subsection{Gaussian Dispersion Results}

The results of the Gaussian dispersion calculations are given in Table 6. Among the species considered, hydrogen has the widest flammability range (40,000-750,000 ppm). At 2.5 years, given the higher hydrogen content, the flammability range is the widest (and consequently, also the isopleth area and the distance downwind between the lower flammability limit (LFL) and the upper flammability limit (UFL) and decreases with time.

Table 6. Results of the Gaussian dispersion calculations, target concentration and relative distance downwind at 2.5, 21 and 30 years.

\begin{tabular}{cccc}
\hline & 2.5 Years & 21 Years & 30 Years \\
\hline LFL $_{\text {mix }}(\mathrm{ppm})^{1}$ & 42,077 & 44,089 & 46,575 \\
$\mathrm{UFL}_{\text {mix }}(\mathrm{ppm})^{1}$ & 376,108 & 260,824 & 194,281 \\
$\mathrm{~A}\left(\mathrm{~m}^{2}\right)$ & 426,421 & 293,567 & 217,647 \\
\hline$\downarrow$ Target $\backslash$ Distance downwind $\rightarrow$ & $\mathbf{2 . 5}$ Years & $\mathbf{2 1}$ Years & 30 Years \\
\hline $\mathrm{LFL}_{\text {mix }}(\mathrm{ppm})^{1}$ & $3100 \mathrm{~m}$ & $2540 \mathrm{~m}$ & $2166 \mathrm{~m}$ \\
$\mathrm{UFL}_{\text {mix }}(\mathrm{ppm})^{1}$ & $794 \mathrm{~m}$ & $854 \mathrm{~m}$ & $906 \mathrm{~m}$ \\
\hline
\end{tabular}

${ }^{1}$ Calculated through Le Chatelier's principle [51].

\subsection{UVCE Calculations}

The flammable amount in the cloud was quantified using van Buijtenen's model for continuous release [38]. The results are reported in Table 7. As seen in Section 3.3, as the time progresses, the extension of the zone in which the cloud concentration is within the flammability limits decreases. Consequently, the mass of fuel contained in the cloud decreases with time. The calculated mass of fuel was used in the TNT equivalency model to calculate the generated overpressure. Figure 3 shows the overpressure $(\mathrm{kPa})$ as a function of the distance downwind. Due to the high hydrogen content, in the case at 2.5 years, the overpressure is always greater than in the other two cases. 
Table 7. Flammable amount in the cloud at 2.5, 21 and 30 years.

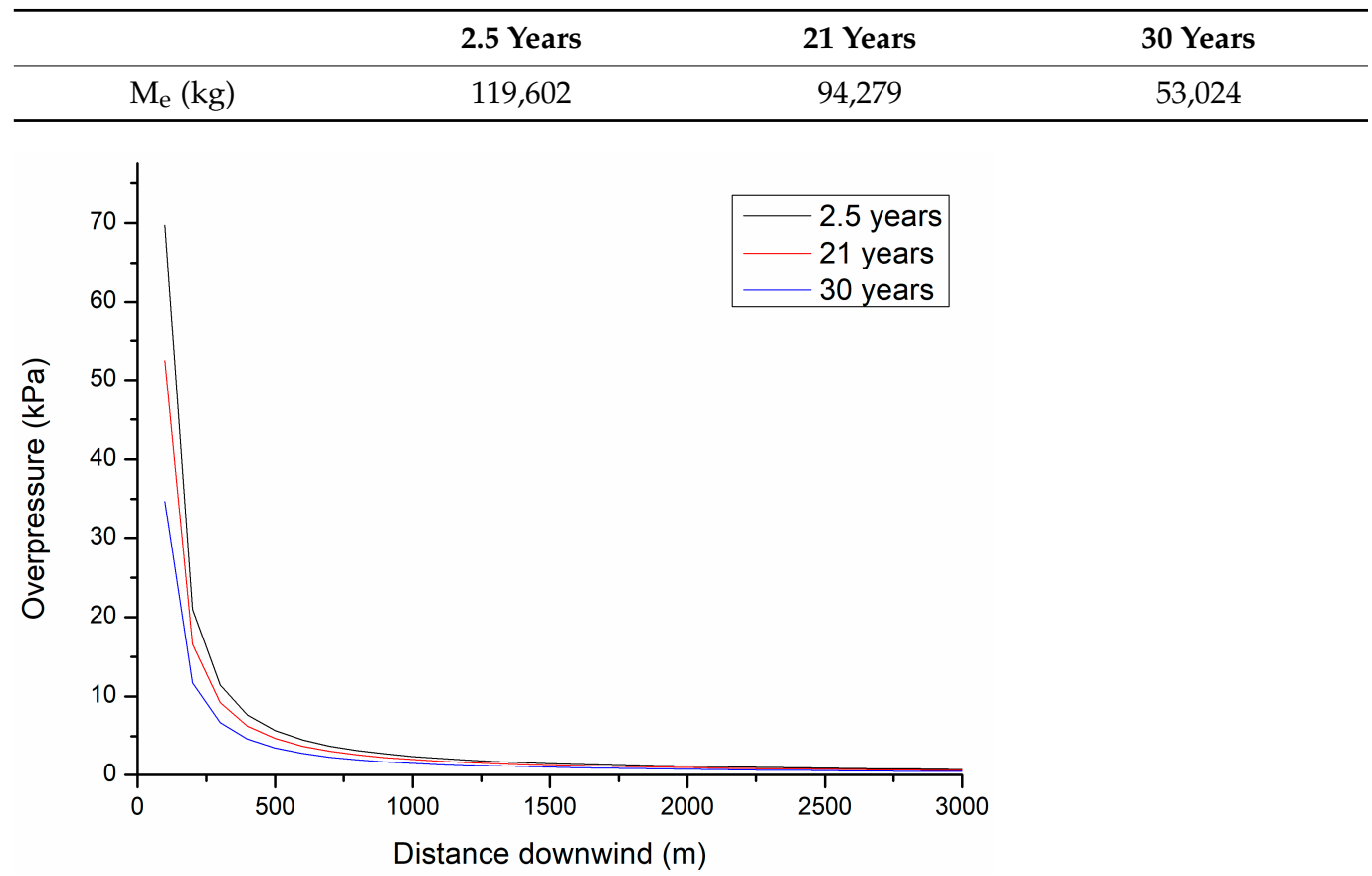

Figure 3. Overpressure (kPa) trend as a function of the distance downwind (m) at 2.5, 21 and 30 years.

\section{5. $\mathrm{H}_{2} \mathrm{~S}$ and $\mathrm{SO}_{2}$ Toxic Release Calculations}

To complete the consequence analysis, calculations of $\mathrm{H}_{2} \mathrm{~S}$ and $\mathrm{SO}_{2}$ dispersion were performed using the dense gas dispersion model (namely, the Britter-McQuaid model). Here, $\mathrm{H}_{2} \mathrm{~S}$ is contained in the underground stored gas due to the reaction of bacteria, and its content increases with time. On the other hand, $\mathrm{SO}_{2}$ is not contained in the stored gas but is produced in the case of $\mathrm{H}_{2} \mathrm{~S}$ combustion. To quantify the $\mathrm{SO}_{2}$ mass flow rate, the complete fuel combustion was considered. Therefore, in this case, the formation of products from the fuel's partial combustion that could also give rise to toxicity problems (e.g., carbon monoxide) was neglected. Tables 8 and 9 show the results of the calculations. In the later years, the iso-level zones are larger due to the higher content of $\mathrm{H}_{2} \mathrm{~S}$ in the gas and the greater mass flow rates of $\mathrm{SO}_{2}$ that can be produced by complete $\mathrm{H}_{2} \mathrm{~S}$ combustion.

Table 8. $\mathrm{H}_{2} \mathrm{~S}$ dispersion calculations using the Britter-McQuaid model.

\begin{tabular}{cccc}
\hline $\mathbf{H}_{\mathbf{2}} \mathbf{S}$ & $\mathbf{2 . 5}$ Years & 21 Years & 30 Years \\
\hline $\mathrm{G}(\mathrm{kg} / \mathrm{s})$ & 9.66 & 23.33 & 35.07 \\
\hline$\downarrow$ Target $\backslash$ Distance downwind $\rightarrow$ & $\mathbf{2 . 5}$ Years & $\mathbf{2 1}$ Years & 30 Years \\
\hline TLV-STEL $(\mathrm{ppm})$ & $3.9 \mathrm{~km}$ & $7.4 \mathrm{~km}$ & $8.3 \mathrm{~km}$ \\
TLV-TWA (ppm) & $5.8 \mathrm{~km}$ & $>10 \mathrm{~km}$ & $>10 \mathrm{~km}$ \\
AEGL-1 $(60 \mathrm{~min})(\mathrm{ppm})$ & $>10 \mathrm{~km}$ & $>10 \mathrm{~km}$ & $>10 \mathrm{~km}$ \\
\hline
\end{tabular}

Table 9. $\mathrm{SO}_{2}$ dispersion calculations using the Britter-McQuaid model.

\begin{tabular}{cccc}
\hline $\mathbf{S O}_{\mathbf{2}}$ & $\mathbf{2 . 5}$ Years & 21 Years & 30 Years \\
\hline $\mathrm{G}(\mathrm{kg} / \mathrm{s})$ & 18.18 & 43.91 & 66.01 \\
\hline$\downarrow$ Target $\backslash$ Distance downwind $\rightarrow$ & $\mathbf{2 . 5}$ Years & $\mathbf{2 1}$ Years & 30 Years \\
\hline TLV-STEL (ppm) & $3.9 \mathrm{~km}$ & $5.3 \mathrm{~km}$ & $6.1 \mathrm{~km}$ \\
TLV-TWA (ppm) & $5.8 \mathrm{~km}$ & $7.8 \mathrm{~km}$ & $8.9 \mathrm{~km}$ \\
AEGL-1 (60 min) (ppm) & $>10 \mathrm{~km}$ & $>10 \mathrm{~km}$ & $>10 \mathrm{~km}$ \\
\hline
\end{tabular}




\subsection{Individual Risk and Effect Zones Calculations}

In order to identify the risk of high-pressure $\mathrm{H}_{2}$ underground storage, the individual risk was calculated and the effect zones at a $50 \%$ fatality level were built. The individual risk is defined as the product of the frequency of the incident outcome (Figure 2) and the probability that the incident outcome will result in a fatality [36]. For a more conservative assessment, each incident outcome case was considered with an equal impact (probability of fatality $=1$ ) throughout its geographical effect zone: within the impact zone, the individual risk is equal to the frequency of that incident outcome case, and outside is equal to 0 [36].

To quantify the dimension of the jet fire effect zone, the fatality levels for different exposure durations and heat fluxes at receptor were used, calculated using the probit model of Eisenberg et al. (1975) [52]. For an exposure duration of $60 \mathrm{~s}$, the thermal flux to have $50 \%$ fatalities is equal to $20 \mathrm{~kW} / \mathrm{m}^{2}$. The effect zone is always centered in the release point.

To quantify the dimension of the UVCE effect zone, an overpressure of $20 \mathrm{kPa}$ ( $3 \mathrm{psi}$ ) was used to calculate the extent of fatal effects at the $50 \%$ level. The effect zone is always centered in the LFL.

To quantify the dimension of the $\mathrm{H}_{2} \mathrm{~S}$ effect zone, the probit correlation for hydrogen sulfide release deaths $\left(K_{1}=-31.42, K_{2}=3\right)$ was used and the value was set at 5.00 [36]. The effect zone is always pie-shaped and centered in the release point.

To quantify the dimension of the $\mathrm{SO}_{2}$ effect zone, the probit function for sulfur dioxide release deaths $\left(K_{1}=-15.67, K_{2}=2.1\right)$ was used and the value was set at 5.00 [36]. The effect zone is always pie-shaped and centered in the release point.

The dimensions of the effect zones for each outcome and time are reported in Table 10. Figure 4 shows an exemplary representation of the effect zones. The dimensions as well as the positions change with time, as reported in Table 10. For the outcomes with an enclosed angle $<360^{\circ}$, only the confidence lines are reported in Figure 4. In Table 11, the total individual risks are reported for each effect zone (numbered as reported in Figure 4). Moreover, all of the outcomes included in a specific effect zone are listed.

Table 10. Effect zone characteristics (center, radius and angle) for each incident outcome and time.

\begin{tabular}{llcccc}
\hline & Jet Fire & $\mathbf{S O}_{\mathbf{2}}$ Toxic Release & UVCE & $\mathbf{H}_{\mathbf{2}} \mathbf{S}$ Toxic Release \\
\hline \multirow{3}{*}{ Center $(\mathrm{m})$} & 2.5 years & 0 & 0 & 3100 & 0 \\
& 21 years & 0 & 0 & 2540 & 0 \\
& 30 years & 0 & 0 & 2170 & 0 \\
\hline \multirow{3}{*}{ Radius $(\mathrm{m})$} & 2.5 years & 75 & 128 & 200 & 16 \\
& 21 years & 76 & 199 & 190 & 22 \\
& 30 years & 78 & 241 & 164 & 32 \\
\hline \multirow{3}{*}{ Angle $\left(^{\circ}\right)$} & 2.5 years & 360 & 40 & 360 & 20 \\
& 21 years & 360 & 39 & 360 & 12 \\
& 30 years & 360 & 20 & 360 & 10 \\
\hline
\end{tabular}

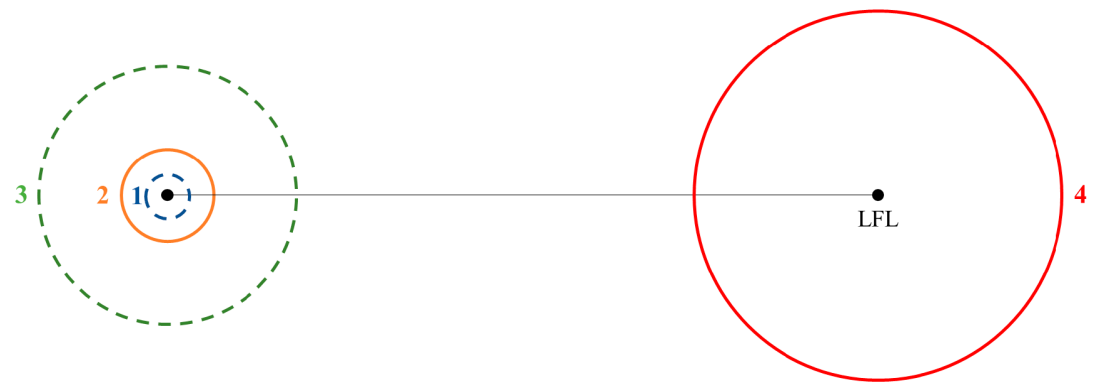

Figure 4. Example of the effect zones. The boundaries of the effect zones are named with numbers (1-4). 
Table 11. Total individual risk (IR) for each effect zone. The outcomes included in each effect zone are listed in the 2 nd column.

\begin{tabular}{ccc}
\hline Effect Zones & Outcomes & IR \\
\hline 1 & $\mathrm{H}_{2} \mathrm{~S}$ toxic release & $5.85 \times 10^{-6} / \mathrm{yr}$ \\
2 & $\mathrm{H}_{2} \mathrm{~S}$ toxic release + Jet fire & $1.24 \times 10^{-5} / \mathrm{yr}^{-5} / \mathrm{yr}$ \\
3 & $\mathrm{H}_{2} \mathrm{~S}$ toxic release + Jet fire $+\mathrm{SO}_{2}$ toxic release & $1.24 \times 10^{-5} / \mathrm{yr}$ \\
4 & UVCE & $5.27 \times 10^{-5} / \mathrm{yr}$ \\
\hline
\end{tabular}

\section{Conclusions}

Underground storage of $\mathrm{H}_{2}$ in salt caverns poses safety issues in terms of fires, explosions and toxic chemical release and dispersion. Due to bacterial metabolism, $\mathrm{H}_{2}$ is converted to $\mathrm{CH}_{4}$. In addition, biotic and abiotic reactions of $\mathrm{H}_{2}$ with sulfates and rocks form $\mathrm{H}_{2} \mathrm{~S}$. Therefore, the composition of the gas contained in the salt caverns varies with time. A quantitative risk assessment was performed, starting from the bow-tie analysis, which shows all the possible causes (basic events) as well as the outcomes (jet fire, UVCE and toxic chemical release). The consequence and risk analyses allowed the quantification of the risk indexes and effect zones, identifying UVCE as the outcome with the highest risk index value. The UVCE effect zone decreases with time due to the hydrogen contamination and the higher contents of methane and hydrogen sulfide. This work can be considered a preliminary tool based on simple models for understanding the risk associated with large-scale hydrogen storage, which is strongly influenced by time and the microbiological composition of the specific salt cavern. This risk assessment, though based on simple models, can, in the future, be applied to specific salt caverns once the microbiological characteristics and the initial composition of the gas to be stored are known. In this way, it will be possible to predict the most suitable storage strategy and establish a good monitoring system to follow and counter potential microbial side effects, especially in the case of leakage.

Author Contributions: Conceptualization, M.P. and A.D.B.; methodology, M.P. and A.D.B.; validation, M.P. and A.D.B.; investigation, M.P. and A.D.B.; writing-original draft preparation, M.P. and A.D.B.; writing — review and editing, M.P. and A.D.B.; supervision, A.D.B. All authors have read and agreed to the published version of the manuscript.

Funding: This research received no external funding.

Institutional Review Board Statement: Not applicable.

Informed Consent Statement: Not applicable.

Conflicts of Interest: The authors declare no conflict of interest.

\section{References}

1. Pethaiah, S.S.; Sadasivuni, K.K.; Jayakumar, A.; Ponnamma, D.; Tiwary, C.S.; Sasikumar, G. Methanol Electrolysis for Hydrogen Production Using Polymer Electrolyte Membrane: A Mini-Review. Energies 2020, 13, 5879. [CrossRef]

2. Al-Juboori, O.; Sher, F.; Khalid, U.; Niazi, M.B.K.; Chen, G.Z. Electrochemical Production of Sustainable Hydrocarbon Fuels from CO2Co-electrolysis in Eutectic Molten Melts. ACS Sustain. Chem. Eng. 2020, 8, 12877-12890. [CrossRef]

3. Khzouz, M.; Gkanas, E.I.; Shao, J.; Sher, F.; Beherskyi, D.; El-Kharouf, A.; Qubeissi, M. Al Life Cycle Costing Analysis: Tools and Applications for Determining Hydrogen Production Cost for Fuel Cell Vehicle Technology. Energies 2020, 13, 3783. [CrossRef]

4. Al-Shara, N.K.; Sher, F.; Iqbal, S.Z.; Curnick, O.; Chen, G.Z. Design and optimization of electrochemical cell potential for hydrogen gas production. J. Energy Chem. 2020, 52, 421-427. [CrossRef]

5. Haroon, M.; Sheikh, N.A.; Ayub, A.; Tariq, R.; Sher, F.; Baheta, A.T.; Imran, M. Exergetic, economic and exergo-environmental analysis of bottoming power cycles operating with CO2-based binary mixture. Energies 2020, 13, 80. [CrossRef]

6. Multiple authors. In-Depth Q\&A: Does the World Need Hydrogen to Solve Climate Change? Available online: www.carbonbrief. org (accessed on 1 May 2021).

7. Schlapbach, L.; Züttel, A. Hydrogen-storage materials for mobile applications. Nature 2001, 414, 353-358. [CrossRef] [PubMed]

8. Wolf, E. Large-Scale Hydrogen Energy Storage; Elsevier B.V.: Amsterdam, The Netherlands, 2015; ISBN 9780444626103. 
9. Kruck, O.; Crotogino, F.; Prelicz, R.; Rudolph, T. Project UE HyUnder: Overview on All Known Underground Storage Technologies for Hydrogen; 2013. Grant agreement no.: 303417. Available online: www.hyunder.eu (accessed on 1 May 2021).

10. Panfilov, M. Underground and Pipeline Hydrogen Storage; Elsevier Ltd.: Amsterdam, The Netherlands, 2016 ; ISBN 9781782423621.

11. Bulatov, G.G. Underground Storage of Hydrogen. Ph.D. Thesis, Moscow Gubkin Oil and Gas University, Moscow, Russia, 1979.

12. Carden, P.O.; Paterson, L. Physical, chemical and energy aspects of underground hydrogen storage. Int. J. Hydrogen Energy 1979, 4, 559-569. [CrossRef]

13. Lindblom, U.E. A conceptual design for compressed hydrogen storage in mined caverns. Int. J. Hydrogen Energy 1985, 10, 667-675. [CrossRef]

14. Paterson, L. The implications of fingering in underground hydrogen storage. Int. J. Hydrogen Energy 1983, 8, 53-59. [CrossRef]

15. Simbeck, D.R. $\mathrm{CO}_{2}$ capture and storage-The essential bridge to the hydrogen economy. Energy 2004, 29, 1633-1641. [CrossRef]

16. Šmigáň, P.; Greksák, M.; Kozánková, J.; Buzek, F.; Onderka, V.; Wolf, I. Methanogenic bacteria as a key factor involved in changes of town gas stored in an underground reservoir. FEMS Microbiol. Lett. 1990, 73, 221-224. [CrossRef]

17. Sinha, N.; Nepal, S.; Kral, T.; Kumar, P. Survivability and growth kinetics of methanogenic archaea at various pHs and pressures: Implications for deep subsurface life on Mars. Planet. Space Sci. 2017, 136, 15-24. [CrossRef]

18. Bernhardt, G.; Jaenicke, R.; Lüdemann, H.D.; König, H.; Stetter, K.O. High Pressure Enhances the Growth Rate of the Thermophilic Archaebacterium Methanococcus thermolithotrophicus without Extending Its Temperature Range. Appl. Environ. Microbiol. 1988, 54, 1258-1261. [CrossRef] [PubMed]

19. Truche, L.; Berger, G.; Destrigneville, C.; Guillaume, D.; Giffaut, E. Kinetics of pyrite to pyrrhotite reduction by hydrogen in calcite buffered solutions between 90 and $180^{\circ} \mathrm{C}$ : Implications for nuclear waste disposal. Geochim. Cosmochim. Acta 2010, 74, 2894-2914. [CrossRef]

20. Dopffel, N.; Jansen, S.; Gerritse, J. Microbial side effects of underground hydrogen storage-Knowledge gaps, risks and opportunities for successful implementation. Int. J. Hydrog. Energy 2021, 46, 8594-8606. [CrossRef]

21. Yang, C.; Jing, W.; Daemen, J.J.K.; Zhang, G.; Du, C. Analysis of major risks associated with hydrocarbon storage caverns in bedded salt rock. Reliab. Eng. Syst. Saf. 2013, 113, 94-111. [CrossRef]

22. Tyldesley, A. Major hazards of natural gas storage. Inst. Chem. Eng. Symp. Ser. 2011, 156, 361-366.

23. Tarkowski, R. Underground hydrogen storage: Characteristics and prospects. Renew. Sustain. Energy Rev. 2019, 105, 86-94. [CrossRef]

24. Zivar, D.; Kumar, S.; Foroozesh, J. Underground hydrogen storage: A comprehensive review. Int. J. Hydrogen Energy 2020. [CrossRef]

25. Reitenbach, V.; Ganzer, L.; Albrecht, D.; Hagemann, B. Influence of added hydrogen on underground gas storage: A review of key issues. Environ. Earth Sci. 2015, 73, 6927-6937. [CrossRef]

26. Amid, A.; Mignard, D.; Wilkinson, M. Seasonal storage of hydrogen in a depleted natural gas reservoir. Int. J. Hydrog. Energy 2016, 41, 5549-5558. [CrossRef]

27. Shen, V.K.; Siderius, D.W.; Krekelberg, W.P.; Hatch, H.W. NIST Standard Reference Simulation Website. NIST Standard Reference Database Number 173 (Last Update to Data Content: September 2017). [CrossRef]

28. Hemme, C.; van Berk, W. Hydrogeochemical modeling to identify potential risks of underground hydrogen storage in depleted gas fields. Appl. Sci. 2018, 8, 2282. [CrossRef]

29. Ebigbo, A.; Golfier, F.; Quintard, M. A coupled, pore-scale model for methanogenic microbial activity in underground hydrogen storage. Adv. Water Resour. 2013, 61, 74-85. [CrossRef]

30. Panfilov, M. Underground Storage of Hydrogen: In Situ Self-Organisation and Methane Generation. Transp. Porous Media 2010, 85, 841-865. [CrossRef]

31. Cord-Ruwisch, R.; Kleinitz, W.; Widdel, F. Sulfate-Reducing Bacteria and Their Activities in Oil Production. JPT J. Pet. Technol. 1987, 39, 97-106. [CrossRef]

32. Levenspiel, O. Chemical Reaction Engineering; Wiley: Hoboken, NJ, USA, 1999; Volume 38, ISBN 047125424X.

33. PARLOC 94: The Update of Loss of Containment Data for Offshore Pipelines; Advanced Mechanics and Engineering Ltd.: Croydon, $\mathrm{UK}, 1996$.

34. Egziabher, T.B.G.; Edwards, S.U.S. Natural Gas Storage Risk-Based Ranking Methodology and Results; Global Security Sciences Division Energy Systems Division: Argonne, IL, USA, 2016. [CrossRef]

35. Mudan, K.S.; Croce, P.A. Fire hazard calculations for large open hydrocarbon fires. In The SFPE Handbook of Fire Protection Engineering, 1st ed.; Springer: New York, NY, USA, 1988.

36. Center for Chemical Process Safety (CCPS). Guidelines for Chemical Process Quantitative Risk Analysis, 2nd ed.; Wiley: Hoboken, NJ, USA, 1999.

37. Available online: https://www.epa.gov/so2-pollution (accessed on 1 May 2021).

38. Van Buljtenen, C.J.P. Calculation of the amount of gas in the explosive region of a vapour cloud released in the atmosphere. J. Hazard. Mater. 1980, 3, 201-220. [CrossRef]

39. Lobato, J.; Cañizares, P.; Rodrigo, M.A.; Sáez, C.; Linares, J.J. A comparison of hydrogen cloud explosion models and the study of the vulnerability of the damage caused by an explosion of H2. Int. J. Hydrogen Energy 2006, 31, 1780-1790. [CrossRef]

40. Li, Y.; Bi, M.; Zhou, Y.; Jiang, H.; Huang, L.; Zhang, K.; Gao, W. Experimental and theoretical evaluation of hydrogen cloud explosion with built-in obstacles. Int. J. Hydrogen Energy 2020, 45, 28007-28018. [CrossRef] 
41. Liu, C.; Wang, Z.; Ma, C.; Wang, X. Influencing factors of the chain effect of spherical gas cloud explosion. Process Saf. Environ. Prot. 2020, 142, 359-369. [CrossRef]

42. Casal, J. Evaluation of the Effects and Consequences of Major Accidents in Industrial Plants, 2nd ed.; Elsevier Inc.: Amsterdam, The Netherlands, 2017.

43. Lees, F.P. Loss Prevention in Chemical Process Industries; Butterworths: London, UK, 1996.

44. Benintendi, R. Process Safety Calculations, 2nd ed.; Elsevier: Amsterdam, The Netherlands, 2021.

45. Britter, R.E.; McQuaid, J. Workbook on the Dispersion of Dense Gases; Health and Safety Executive (Open Source): Bootle, UK, 1988

46. Hanna, S.R.; Chang, J.C.; Strimaitis, D.G. Hazardous gas model evaluation with field observations. Atmos. Environ. Part A Gen. Top. 1993, 27, 2265-2285. [CrossRef]

47. Hanna, S. Britter and McQuaid (B\&M) 1988 workbook nomograms for dense gas modeling applied to the Jack Rabbit II chlorine release trials. Atmos. Environ. 2020, 232, 117539. [CrossRef]

48. Goddard \& Goddard Engineering. Environmental Studies: Screening of Selected Accidental Release Scenarios Originating from Abandoned California Department of Water Resources South Geysers Unit 15 Well Field Sonoma County, CA. 1997, Volume 1917. Available online: https:/ / semspub.epa.gov (accessed on 1 May 2021).

49. Energy Resources Conservation Board. ERCBH2S: A Model for Calculating Emergency Response and Planning Zones for Sour Wells, Sour Pipelines, and Sour Production Facilities, Volume 1: Technical Reference Document, Version 1.20; Energy Resources Conservation Board: Calgary, AB, Canada, 2010; Volume 1.

50. Bank, W. Manual of Industrial Hazard Assessment Techniques; Kayes, P.J., Ed.; The World Bank: Washington, DC, USA, 1985.

51. Le Chatelier, H.L. Note sur le dosage du grisoupar les limetes de'inflammabilite. Ann. Mines 1891, 19, 388-395.

52. Eisenberg, N.A.; Lynch, C.J.; Breeding, R.J. Vulnerability Model. A Simulation System for Assessing Damage Resulting from Marine Spills; Final Report; U.S. Department of Energy Office of Scientific and Technical Information: Washington, DC, USA, 1975. 